\title{
FINANCIAL MANAGEMENT ELEMENTS SPECIFIC TO THE EVALUATION OF RESEARCH-DEVELOPMENT-INNOVATION (RDI) ACTIVITIES
}

\author{
Bianca Cezarina Ene ${ }^{1}$ \\ Adrian Ioana $^{2}$ \\ Daniela Tufeanu ${ }^{3}$ \\ Daniela Ionela Juganaru ${ }^{4}$ \\ Daniela Alice Luta (Manolescu) ${ }^{5}$
}

DOI: https://doi.org/10.31410/LIMEN.2020.343

\begin{abstract}
This article presents the main elements specific to the evaluation of research and development and innovation activities: evaluation of scientific research activity; evaluation of the staff involved; valuation of tangible assets; valuation of intangible assets. Also, we present in the article the two ways of approaching the evaluation of research, development, innovation: macroeconomic approach; microeconomic approach. The comparative analysis is based on the management by results and the management by objectives in the field of research activities, development, and innovation. In this context, we present the economic-financial indicators used in the evaluation of the research, development, innovation: the rate of new sales; cost savings rate; revenues from research development innovation.
\end{abstract}

Keywords: Financial management, Research, Development, Innovation.

\section{INTRODUCTION}

7 he research-development-innovation activity (RDI) plays an important role in the success and development of enterprises, in their strategic positioning. In the evaluation of the RDI activity, we distinguish four essential elements (Ioana, 2009; Nicolescu, 1993): valuation of the scientific research activity; evaluation of the staff involved; valuation of tangible assets, and valuation of intangible assets along with two following approaches.

The macroeconomic approach that takes into account the extent to which the state administration bodies at the national or local level administer the RDI activity and direct the allocated funds, either from the national budget or from international collaboration programs (e.g. European programs, or programs established with the USA, Japan, Canada, Russia, China, etc.)

Microeconomic approach concerning the role of the management of the institutions with attributions in the field of RDI in the management of the financial resources allocated or obtained from their activity.

University Politehnica of Bucharest, Spl. Independentei 313, Bucharest, Romania University Politehnica of Bucharest, Spl. Independentei 313, Bucharest, Romania University Politehnica of Bucharest, Spl. Independentei 313, Bucharest, Romania University Politehnica of Bucharest, Spl. Independentei 313, Bucharest, Romania University Politehnica of Bucharest, Spl. Independentei 313, Bucharest, Romania 
The comparative analysis is based on management by results and management by objectives in the field of RDI (Nicolescu, 2000; Ioana et al., 2019) and represents the vision of researchers, a system of procedures and principles for the allocation of resources and rewards.

Among the requirements of the comparative analysis are:

- importance of the RDI field, but also the research topic at macro and microeconomic level;

- the capacity of the enterprise to complete the project;

- side effects of program application;

- results of the RDI activity and the technological progress, development of the scientific infrastructure;

- requested financial support and own contribution.

\section{ECONOMIC - FINANCIAL INDICATORS USED IN THE EVALUATION OF THE RDI}

Among the most important indicators used in the RDI activity we can mention (Nicolescu, 1993; Costoiu \& Semenescu, 2015) the following.

\section{New sales rate $(R V N)$}

This indicator of sales revenues in a year "i $i$ " results from the improvement of the product marketed in the period from " $i-j$ " to "i-l" compared to the total revenues from the year "i" $(V T)$, i.e.:

In which:

$$
R V N=\frac{1}{V T_{\text {rev }}} \times \sum_{N=i-l}^{N=1-l} V N_{\text {vanz }}
$$

$\boldsymbol{V T}=$ Total revenue for a year "i"

$V N_{\text {vanz }}=$ Net income in a year " $\mathrm{i}$ " from the improvement of the product marketed in a year "i"

\section{Cost saving rate (REC)}

This indicator expresses the cost savings of goods sold in a year "i" from the adoption of an innovative process that led to the change of the product in the period "i-k" to "i-l" and the obtaining of an average gross profit in a year " $i$ ", ie:

$$
R E C=\frac{1}{P M B} \times \sum_{N=i-k}^{N=1-l} R C_{e c}
$$

Where:

$\boldsymbol{R} \boldsymbol{C}_{\boldsymbol{e}}=$ reduction in costs of goods sold in a year "i" by the use of innovative processes in year $\mathrm{N}$

$\boldsymbol{P M B}=$ Gross Average Profit for the business unit in a year "i"

\section{Revenue from RDI (RDI $\left.{ }_{v e n}\right)$}

This indicator is given by the contribution in the gross profit $(\boldsymbol{P B})$ which represents the sale of 
new or modernized products $(N P)$ and the decrease of the cost of new products by introducing innovative technologies $(\boldsymbol{S C})$.

$$
R D I_{\text {ven }}=N P+S C
$$

\section{Predicted RDI / Created Value (VC), Portfolio Analysis (AP)}

The Expected Sales Value is characterized by the percentage of future sales from the total of $R D I$ projects and incorporates the probability of achieving the objectives of each project at the level of one year.

The Value of Projected Revenues given by the percentage of the future net annual revenues (and/or profitability) from the total RDI projects and which incorporates the probability of achieving the objectives of each project at the level of the 1-year period.

In addition to the indicators presented, we can also list others that have a special significance in the RDI activity.

- Distribution of investments in new technologies / Portfolio Evaluation for Projects (EPP).

- The share of patents (PBI) in the Value of technological assets (VAcT)

$$
P B I=(N B I / V A c T) \times 100 \quad[\%]
$$

Where:

$N B I=$ Number of patents

- Share of current investments in new technologies (PICTN) related to the value of technological assets (VAcT)

$$
P I C T N=(I C T N / V A c T) \times 100 \quad[\%]
$$

Where:

ICTN = Current investments in new technologies.

\section{FINANCIAL MANAGEMENT ELEMENTS SPECIFIC TO RDI ACTIVITIES, INCLUDING EUROPEAN-FUNDED SCIENTIFIC RESEARCH PROJECTS}

In general, the design and implementation of the call for tender for a European-funded scientific research project require a pre-feasibility and/or feasibility study specific to that project. Also, the activity of research, development, innovation (RDI) in general and scientific research projects with European funding in particular, require scientific financial management of all types of resources (human, financial, material, and informational).

Of particular importance is the achievement of an estimated (when submitting the offer request) realistic, viable, and very well argued and substantiated Expenditure Estimate. We will present later in the paper the examples of such estimates of estimated expenses. 


\subsection{Analysis of variable expenses}

Within the operating expenses, the variable part, respectively the one that is dependent on the volume of activity, is predominant. Economic theory and practice use the notions of proportional and disproportionate dependence.

In the first case it is expressed by the relation:

$\mathrm{a} \cdot \mathrm{Q}$ and in the second case by functions $\mathrm{f}(\mathrm{Q})$

where:

a - the sum of variable costs per product;

$\mathrm{Q}$ - the number of products.

The analysis of variable expenditures in economic practice is justified by:

- elaboration of sales policies depending on the degree of profitability and consequently on the contribution to the coverage of common expenses;

- elaboration of the necessary cost budgets, in the good management of all categories of resources;

- establishing the implementation strategy from a quantitative point of view and the deadline;

- determining the break-even point, a particularly important issue in the dimensioning of some activities and categories of expenses.

Of course, some reservations can be made in this regard, determined by:

- the inaccuracy of establishing the variability of different categories of expenses;

- the impact of the salary system on the two groups of expenses (variable orfixed).

\subsection{Analysis of the dynamics and structure of variable expenditures}

In order to follow the dynamics of the total variable expenses at 1,000 RON income, we use the data from table 1.

Table 1. Analysis of the dynamics and structure of variable expenditures

\begin{tabular}{|c|l|c|c|c|c|}
\hline \multirow{2}{*}{$\begin{array}{l}\text { Nr. } \\
\text { crt. }\end{array}$} & \multicolumn{1}{|c|}{ Indicators } & $\begin{array}{c}\text { Previous } \\
\text { period Pn-1 }\end{array}$ & $\begin{array}{c}|c| \\
\text { Provided } \\
\text { Po }\end{array}$ & $\begin{array}{c}\text { Accomplished } \\
\text { P1 }\end{array}$ & \multirow{2}{*}{$\frac{P_{1}}{P_{0}}$} \\
\hline 1. & $\begin{array}{l}\text { Variable operating } \\
\text { expenses }\end{array}$ & 3,974 & 4,772 & 5,092 & 106.70 \\
\hline 2. & $\begin{array}{l}\text { Variable expenses related } \\
\text { to turnover }\end{array}$ & 3.792 & 4.648 & 5.032 & 108,26 \\
\hline 3. & $\begin{array}{l}\text { Variable expenses related } \\
\text { to the calculated turnover }\end{array}$ & 3.808 & $\mathrm{X}$ & 4.990 & $\mathrm{X}$ \\
\hline 4. & Fiscal value & 7.360 & 8.436 & 9.260 & 109,77 \\
\hline 5. & Operating income & 6.770 & 8.014 & 8.750 & 109,18 \\
\hline 6. & Turnover increased & 6.600 & $\mathrm{X}$ & 9.000 & $\mathrm{X}$ \\
\hline 7. & $\begin{array}{l}\text { Variable operating } \\
\text { expenses per 1.000 RON } \\
\text { operating income (1/4) }\end{array}$ & 540,00 & 565,67 & 550,00 & 97,22 \\
\hline
\end{tabular}




\begin{tabular}{|l|l|l|l|l|l|}
\hline 8. & $\begin{array}{l}\text { Variable expenses per } \\
1.000 \text { RON turnover (2/5) }\end{array}$ & 560,00 & 580,00 & 575,00 & 99,14 \\
\hline
\end{tabular}

Source: Own research

Following the evolution of variable expenses to $1,000 \mathrm{RON}$ operating income and turnover, respectively, compared to the achievements of the previous year and provisions, this is different. Thus, an increase of variable expenses to 1,000 RON operating income and turnover was foreseen. However, there are reductions in comparing the achievements with the provisions.

\section{CONCLUSION}

The evaluation of the research-development-innovation activities (RDI) supposes the completion of the following stages: the evaluation of the scientific research activity; evaluation of the staff involved; valuation of tangible assets; valuation of intangible assets. There are two ways to approach this evaluation activity: the microeconomic approach and the macroeconomic approach.

The most important economic-financial indicators used in the evaluation of the research, development, innovation, and innovation are new sales rate (RVN); RDI income; the share of patents (PBI) in the value of technological assets (VAcT); the share of current investments in new technologies (PICTN) related to the Value of technological assets (VAcT); distribution of investments in new technologies / Project Portfolio Evaluation (EPP).

Among the financial management methods specific to research-development-innovation (RDI) activities, including European-funded scientific research projects, the most important are: the analysis of variable expenditures; analysis of the dynamics and structure of variable expenditures.

\section{REFERENCES}

Costoiu, M., Semenescu, M. (2015) Economic-Financial Analysis - Theory and Applications, Coordinator: A. Ioana, A. Marcu, D. Barbu CA, Matrix Rom Publishing House, ISBN 978-606-25-0196- 9, Bucharest.

Ioana, A. (2009) Management of financial-accounting activity and economic analysis. Theory and Applications, Politehnica Press Publishing House, ISBN: 973-7838-20-3, Bucharest.

Ioana, A., Tufeanu, D., Labes, D.C. (2019) Financial Management. Theory and Applications., Ed. Printech, ISBN 978-606-23-1017-2, Bucharest.

Nicolescu, O. (1993) The guide of the efficient manager, Technical Publishing House, Bucharest.

Nicolescu, O. et al. (2000) Management Systems, Methods and Techniques of the Organization, Economic Publishing House, Bucharest. 